\title{
Genetic patent singles out Jewish women
}

\section{MUNICH}

Europe's rules for gene patenting are under attack for allowing racial discrimination. On 29 June, the European Patent Office (EPO) upheld a patent that will mean Ashkenazi Jews have to pay for screening for a particular breast-cancer gene.

The patent, on the BRCA2 gene, was filed by Myriad Genetics of Salt Lake City in Utah, although the company has since transferred ownership to a consortium that includes the

\section{"This is a moral} not a legal issue." sequence as first registered (see Nature 433, $344 ; 2005)$. The BRCA2 sequence seems to be correct, but the consortium has refocused its $B R C A 2$ patent on the point where its claims of intellectual ownership are strongest - a mutation that seems to be found exclusively in Ashkenazi Jews.

The EPO decision means that European patients will be asked whether they are Ashkenazi. If they are, they will have to pay the same high royalties for BRCA2 testing that University of Utah Research Foundation. It was submitted in 1996, granted in 2003, and originally covered all possible research and diagnostic tools involving the gene. After challenges, the consortium narrowed the patent's scope to cover the diagnosis of a particular mutation in Ashkenazi Jews.

In January, a European patent that Myriad filed on the related $B R C A 1$ gene was revoked, because critics revealed errors in the DNA
US doctors have to demand from all patients - the US patent office has granted broad versions of both the BRCA1 and BRCA2 patents.

The Munich-based EPO has granted patents on hundreds of individual genes. But very few patent holders demand licence fees from public health dinics. When Myriad bucked that trend, many European clinics decided to ignore its royalty requests. And various geneticists challenged Myriad's patents.
Those challengers are unhappy with last week's result. ${ }^{\alpha}$ We are thinking about whether to appeal again, but given the general rules of the EPO, the basis on which we might be successful is not obvious," says Gert Matthijs of the Centre for Human Genetics at Belgium's Catholic University of Leuven.

Dorit Lev, head of the Israel Association of Medical Geneticists, says that the situation is unacceptable. Ashkenazi Jewish women with this mutation frequently develop breast cancer. A simple genetic test identifies those at risk and screening is routine. "It's not right that they should be discriminated against," says Lev.

The only option for opponents is to press for changes to the grounds on which the EPO grants patents. ${ }^{\alpha}$ This is a moral not a legal issue and we are now thinking about challenging the political basis of the European rules", says Mary Rice, spokeswoman for the Vienna-based European Society of Human Genetics.

Alison Abbott 